\title{
Evaluasi Penganggaran, Pengalokasian dan Pelaporan Dana Desa Sumber Salak Kec Ledokombo Kabupaten Jember
}

\author{
Anggik Agus Setiawan ${ }^{1}{ }^{*}$, Norita Citra $^{2}$, Ade puspito ${ }^{3}$ \\ 1,2,3 Jurusan Akuntansi, Fakultas Ekonomi, Universitas Muhammadiyah Jember (UMJ)
}

\section{A R T I C L E I N F O}

Article history:

Received 18 August 2018

Received in revised form

20 September 2018

Accepted 20 October 2018

Available online 26

November 2018

\section{Kata Kunci:}

Penganggaran

Pengalokasian dan

Pelaporan Dana Desa.

Metode Kualitatif

Keywords:

Accounting Information

System Manual and

Foundation

\begin{abstract}
A B S T R A K
Studi ini bertujuan untuk mengamati kesesuaian antara aturan dana desa dengan pelaksanaanya, serta implementasi dan dampak dan penggunaan dana desa tersebut dalam menunjang aktivitas pembangunan dan pemberdayaan masyarakat metode penelitian yang digunakan adalah metode penelitian kualitatif yang bertumpu pada pengamatan tempat, aktor dan aktivitas yang ada di Dese Sumber Salak Kecamatan Ledokombo Kabupaten Jember yang dipilih studi kasus. Hasil penelitian menunjukkan bahwa terdapat indikasi kesesuaian antara aturan yang telah ditetapkan mengenai dana desa dan pelaksanaannya, indikasi tersebut tampak pada pelaksanaan transfer penggunaan dan pelaporan dana desa. Meskipun demikian dalam proses pencairan dana desa tidak sesuai dengan aturan karena mengalami keterlambatan. Dalam implementasinya penggunaan dana desa cukup menunjang aktivitas penggunaan dan pemberdayaan masyarakat. Untuk menunjang pembangunan desa, di implementasi dengan adanya perbaikan jalan sedangkan dalam pemberdayaan masyarakat dana desa digunakan untuk pendirian BUMDes dan bantuan PAUD implementasi tersebut ada yang berdampak produktivitas ekonomi dan sosial.
\end{abstract}

\section{A B S T R A C T}

This study aims to observe the suitability of the village funding rules and their implementation, and the implementation and impacts and uses of the village funds in support of development activities and community empowerment research method used is qualitative research methods that rely on observation of places, actors and activities in Dese Sumber Salak Kecamatan Ledokombo Jember District selected case study. The results indicate that there is an indication of conformity between the established rules of village funds and their implementation, the indications shown in the implementation of the transfer of use and reporting of village funds. Nevertheless, in the process of disbursing the village funds are not in accordance with the rules due to delay. In the implementation of the use of village funds is sufficient to support the activities of use and community empowerment. To support the development of the village, in the implementation with the improvement of the road while in the community empowerment of village funds used for the establishment of BUMDes and PAUD assistance implementation there is an impact on economic and social productivity.

\footnotetext{
* Corresponding author.

E-mail addresses: anggiksetiawan@gmail.com (Anggik Agus Setiawan)
} 


\section{Pendahuluan}

Indonesia merupakan negara yang memiliki wilayah yang sangat luas yang terdiri dari beberapa Provinsi, disetiap provinsi dibagi-bagi menjadi beberapa tingkatan wilayah yaitu Kabupaten atau Kota yang juga terbagi menjadi Kecamatan, dimana Kecamatan ini dibagi lagi menjadi wilayah yang lebih kecil yaitu kelurahan dan Desa (Niswati, 2016). Untuk meningkatkan pembangunan di Desa, Pemerintah Indonesia telah berupaya membuat program pemberdayaan Desa dimana diharapkan perangkat Desa bersama masyarakatnya dapat secara mandiri bekerjasama untuk membangun dan memajukan Desa tempat mereka tinggal tentunya dibawah pengawasan Pemerintah Kabupaten (Aldera,2014).

Upaya semua Negara untuk menyejahterakan warganya adalah melalui proses pembangunan, tidak terkecuali Negara Indonesia yang terdiri dari Provinsi sampai Kelurahan dan Desa. Menurut Musmini (2016) Indonesia sebagai sebuah Negara dibangun diatas dan dari Desa, Desa merupakan pelopor sistem demokrasi yang otonom dan berdaulat penuh. Desa merupakan bagian terkecil dari struktur Pemerintah yang ada di structural Kepemerintah Indonesia, Desa sebagai bagian terkecil dari Kepemerintahan mempunyai wewenang dalam merencanakan pembangunan untuk memajukan dan meningkatkan kesejahteraan Masyarakat, dan Pemerintah Desa yang paling dekat dan paling mengetauhinya segala kebutuhan Masnyarakatnya (Thomas,2013). Peraturan meteri dalam negeri Republik Indonesia Nomor 114 tahun 2014 menyatakan bahwa kewenangan Desa adalah kewenangan yang dimiliki Desa meliputi kewenangan di bidang penyelenggaraan pemerintah desa, pelaksanaan pembangunan Desa, pembinaan masyarakat, hak asal usul dan adat istiadat (Rizaldi, 2012).

Pembangunan Desa harus dilaksanakan dengan persiapan yang terencana dengan baik dan dapat dipertangungjawabkan. Menurut Peraturan menteri dalam Negeri Republik Indonesia Nomor 11 tahun 2014, perencanaan pembangunan Desa adalah proses tahapan kegiatan yang diselengarakan oleh pemerintah Desa dengan melibatkan badan permusyawaratan Desa dan unsur masnyarakat secara partisipatif guna pemanfaatan dan pengalokasian sumberdaya Desa dalam rangka mencapai tujuan pembangunan Desa (Grabowski,2011). Pembangunan partisipatif adalah suatu sistem pengelolaan pembangunan di Desa dan kawasan pedesaan yang dikoordinasikan oleh kepala Desa dengan mengedepankan kebersamaan, kekeluargaan, dan ke gotongroyongan guna mewujudkan pengurus utama perdamaian dan keadilan sosial. Bahwa dalam rangka melaksanakan ketentuan Pasal 96 ayat (4) Peraturan Pemerintah Nomor 43 Tahun 2014 tentang Peraturan Pelaksanaan Undang-Undang Nomor 6 Tahun 2014 tentang Desa, perlu mengatur dan menetapkan Pedoman Pengelolaan Alokasi Dana Desa di Kabupaten Jember Tahun Anggaran 2016.

Kabupaten Jember merupakan salah satu daerah yang menerima anggaan Dana Desa yang selanjutnya akan disalurkan ke setiap Kecamatan yang ada di Kabupaten Jember. Menurut peraturan Daerah Kabupaten Jember Nomor 5 Tahun 2016, 7 Tentang Pengelolaan Kekayaan Milik Desa Bahwa (1) Anggaran ADD dikelola dala APBDesa dan d gunakan untuk membiayai kegiatan penyelenggaraan pemerintah Desa, pelaksanaan pembangunan Desa, pembinaan kemasnyarakatan, pemberdayaan masnyarakat dan bidang yang tidak terduga (2) Anggaran ADD diperioritaskan untuk membiayai kegiatan bidang penyelenggaraan Pemerintah Desa, Bidang pemberdayaan Masnyarakat dan bidang pelaksanaan pembangunan Desa (3) Pemerintah Desa menyusun bentuk kegiatan yang d biayai ADD dengan mengacu pada dokumen RPJMDesa dan RKPDesa (4) Contoh bentuk kegiatan sebagaimana dimaksud pada ayat (3) sebagaimana tercantum dalam lampiran 1 yang merupakan bagian tidak terpisahkan dari peraturan Bupati ini.

Proses pembangunan Desa selain memerhatikan sistem perencanaan, juga perlu memperhatikan dana Desa, Dana Desa adalah dana yang bersumber dari anggaran pendapatan dan belanja negara yang di peruntukkan bagi Desa yang ditransfer melalui anggaran pendapatan dan belanja daerah Kabupaten/Kota dan digunakan untuk membiayai penyelenggaraan Pemerintah, pelaksanaan pembangunan, pembinaan kemasyarakatan dan pemberdayaan Masyarakat. Peningkatan keterlibatan masyarakat atau partisipasi dalam pembangunan daerah di kemukakan oleh Lilian, 2017 sebagai berikut: Pertama adalah mobilisasi kegiatan-kegiatan masnyarakat serasi untuk kepentingan-kepentingan pencapaian tujuan pembangunan, kedua adalah dengan meningkatkan aktivitas, swadaya dan swakarya masyarakat sendiri. Pada cara yang pertama, partisipasi masnyarakat yang lebih didasarkan pada hubungan satu arah dan atas kebawah, sedangkan pada cara kedua terutama ditujukan kepada sektor usaha swasta. Perhatian khusus kepada golongan masnyarakat tertentu dapat berperan penting dalam meningkatkan partisipasi dalam pembangunan.

Menurut (Abdul Wahab, 2000), menyatakan bahwa masyarakat merasa adanya pelibatan terhadap dirinya berkaitan dengan pembangunan terbatas hanya dalam musyawarah dusun, itupun sebatas pemerintah desa agar masnyarakat mengajukan usul-usul berkaitan dengan pembangunan. Namun 'nasib' dari pada usulan-usulan tersebut, sebagian masnyarakat tidak tahu bagaimana kelanjutanya (Suputra, 
2016). Dana desa sangat rentan untuk disalahgunakan, karena setelah dana trasfer disalurkan kedaerah, maka dana tersebut menjadi hak tangungjawab dari pemerintah daerah (Aswardi, 2014). Melihat masalah dana transfer yang sering disalahgunakan oleh desa itu sendiri, seharusnya dana tersebut untuk membangun desa dan pemberdayaan masnyarakat, tetapi dana yang bersumber dari APBN itu tidak dimanfaatkan untuk pembangunan desa dan pemberdayaan masnyarakat (Setiawan, 2016). Oleh karena itu, seharusnya Badan Permusnyawaratan daerah ikut serta dalam pengalokasian dana dari APBN sehingga tidak terjadi penyelewengan atau penyalahgunaan. Jadi harus dilakukan pemantauan dan evaluasi terhadap dana dari APBN yang di dampingi oleh Badan permusnyawaratan Daerah dan masnyarakat itu sendiri.

Berdasarkan monitoring dan evaluasi ini penting dilakukan mengingat dana yang disalurkan sebagai dana transfer ke daerah sebagai perimbangan dari pemerintah pusat ke pemerintah daerah (Desa) ini tidaklah sedikit (Darmada,2016). Selain itu, mengingat perekonomian Indonesia yang cenderung melambat dalam satu tahun terahir, sehingga diperlukan percepatan penyerapan anggaran, guna menstabilkan perekonomian di indonesia dan mendukung kemandirian daerah serta keberhasilan otonomi daerah, membutuhkan pemerintah dan pemerintah daerah yang kuat dan yang mampu menjaga hubungan keuangan yang sejalan dengan perkembangan dan kebutuhan masnyarakat saat ini, dana desa sudah tersalur sebesar $90 \%$. Hal ini bukan berarti menyisakan masalah panduan penggunaanya, belum jelas meskipun secara umum dinyatakan bahwa penggunaan dana desa diutamakan untuk mendorong program prioritas pemerintah terutama di bidang infrastruktur (Sari,2015).

Setiap tahun pemerintah Desa, mendapatkan dana desa yang dihitung berdasarkan alokasi dasar yang merupakan alokasi yang dibagi secara merata kepada setiap desa sebesar 90\% (sembilan puluh persen) dari dana desa dan 10\% (sepuluh persen) secara proposional (Pemerintah daerah Kab Jember) (Sumber: Kec Ledokombo). Penelitian ini dilakukan di desa Sumber Salak Kecamatan Ledokombo yang merupakan salah satu desa yang ada di Kabupaten jember. Desa Sumber Salak ini masih mebutuhkan sarana dan prasarana fisik dalam menunjang kesejahteraan masnyarakat desa dan pemberdayaan masnyarakat dan untuk melaksanakan proses pembangunan desa. Pemerintah juga membutuhkan banyak biaya untuk pembangunan desa dan salah satunya pemerintah pusat yang dapat menunjang dalam meningkatkan pemberdayaan masnyarakat yaitu dengan memberikan dana berupa dana desa yang ditransfer melalui anggaran pendapatan dan Belanja dana desa (APBD) dan pemberian Dana Desa dari Pemerintah Kabupaten Jember untuk desa diharapkan mampu meningkatkan kesejahteraan masnyarakat desa.

\section{Metode}

Hasil reduksi data kemudian disusun dan disajikan dalam bentuk teks naratif-deskriptif. Tahap penyajian data berisi tentang pengelolaan data setengah jadi yang udah seragam dalam bentuk tulisan dan sudah memiliki alur tema yang jelas kedalam suatu matriks kategorisasi sesuai tema-tema yang sudah dikelompokkan dan dikategorikan, serta akan memecahkan tema-tema tersebut ke dalam bentuk yang lebih konkret dan sederhana.

Langkah-Langkah dalam Reduksi Data

a. Membandingkan pelaksanaan Penganggaran, Pengalokasian dan Pelaporan Dana Desa menurut Permendagri dan Menurut Kantor Desa Sumber Salak.

1. Penganggaran, Pengalokasian dan Pelaporan menurut Permendagri

Pengalokasian untuk Kabupaten/Kota yang di perhatikan jumlah penduduk, Angka kemiskinan, Luas wilayah, Serta kesulitas geografis Desa sebesar 10\%.

2. Pengalokasian menurut Kantor Desa Sumber Salak

Prioritas penggunaan Dana Desa, Penyusunan dan penyampaian laporan realisasi penggunaan Dana Desa.

b. Indentiifikasi Faktor-Faktor Penghambat dalam Pelaporan, Pengalokasian dan Pelaporan Dana Desa

\section{Hasil dan pembahasan}

Keuangan Desa Sumber Salak bersumber dari berbagai aspek, ada yang dari luar Desa maupun berasal dari dalam Desa Sumber Salak itu sendiri, ada tiga macam keuangan Desa yaitu PAD (Pendapatan Asli Daerah), DD (Dana Desa), ADD (Alokasi Dana Desa) berikut penjelasanya:

1. PAD (Pendapatan Asli Desa) : a. Hasil Aset (Sewa tanah kas Desa), b. Swadaya, Pertisipasi dan gotong royong, c. Pasar Desa (Pendapatan asli Desa yang sah) 
2. Pendapatan Transfer:a. Dana Desa, b. Bagian Dari hasil pajak dan retribusi daerah Kabupaten/Kota diantaranya, bagi hasil Pajak Daerah dan bagi Hasil Retribusi Daerah, c. Alokasi Dana Desa, d. Bantuan keuangan meliputi bantuan Provinsi dan b antuan Kabupaten/Kota

3. Pendapatan Lain-lain : a. Hibah dan sumbangan Pihak ke-3 yang tidak mengikat dan b. Lain-lain pendapatan Dana Desa yang sah

Dana Desa adalah dana yang ditransfer dari pemerintah pusat ke pemerintah desa, desa adalah semua hak dan kewajiban desa yang dapat dinilai dengan uang serta segala sesuatu berupa uang dan barang yang berhubungan dengan pelaksanaan hak dan kewajiban desa. Hak dan kewajiban tersebut menimbulkan pendapatan, belanja, pembiayaan yang perlu diatur dalam pengelolaan keuangan desa yang baik. Siklus pengelolaan keuangan desa meliputi perencanaan, pelaksanaan, penatausahaan, pelaporan dan pertanggungjawaban, dengan periodisasi 1 tahun anggaran, terhitung mulai tanggal 1 januari sampai dengan 31 desember.

\section{Analisis Data}

Membandingkan Mekanisme Penganggaran Menurut Desa Sumber Salak dengan Peraturan Permendagri

Menurut Desa Sumber Salak

Penganggaran menurut Desa Sumber Salak, Dalam melakukan penganggaran yang dilakukan Desa Sumber Salak, Dana Desa yang dikelola oleh Desa Sumber Salak secara umum untuk meninggkatkan pemberdayaan masyarakat dan menunjang pembangunan Desa Sumber Salak adalah dapat menanggulangi kemiskinan, meringankan beban keuangan desa untuk menunjang pembangunan yang ada di desa sumber salak Dalam melakukan penganggaran haruslah Tranparan, Partisipatif, Disiplin, Keadilan, Efesien dan efektivitas dan Rasonal dan terukur, penganggaran adalah suatu rencana yang disajikan kuantitatif yang disajikan dalam satuan keuangan yang ada di desa Sumber Salak. Sebelum Desa Sumber Salak membuat RKPBDes terlebih dahulu Desa menyusun RPJMDes, ada beberapa tahapan di Desa Sumber Salak: a) Melakukan Musdus di 4 Dusun yang ada di Desa Sumber Salak, b) melakukan Musrembangdes membahas apa pembangunan apa yang dibutuhkan oleh setiap Dusun yang ada di Desa Sumber Salak, c. Menyusun RKPJMDes dan RKPBDes untuk tahun anggaran 1 tahun, d. Lalu RKPBDes yang sudah ditetapkan akan dikirim ke Pemerintah pusat.

\section{Menurut Peraturan Permendagri}

Penganggaran menurut Permendagri Dana Desa yang bersumber dari anggaran pendapatan belanja Negara yang diperuntukkan bagi Desa yang ditransfer melalui anggaran pendapatan Belanja daerah Kabupaten/Kota dan digunakan untuk membiayaai penyelenggaraan pemerintah, pelaksanaan pembangunan, pembinaan kemasyarakatan dan pemberdayaan masyarakat, Penganggaran yang ada di Desa Sumber Salak sudah menerapkan penganggaran yang diatur dalam peraturan permendagri yaitu menggunakan pedoman seperti transparan, partisipatif, disiplin, keadilan, keadilan, efisien dan efektifitas, Rasional dan terukur, menyetujui RKPBDes yang sudah di ajukan oleh Desa.

Setelah dilihat yang dilakukan pemerintah Desa Sumber Salak sudah mengacu dengan peraturan Permendagri, Sebelum Desa membuat RPJMDes dan RKPBDes Desa Sumber Salak terlebih dulu melakukan musyawarah Dusun dan Juga Musyawarah Desa agar tidak ada yang ditutup-tutupi dalam melakukan kegiatan ataupun Pembangunan Desa Sumber Salak.

Membandingkan Mekanisme Pengalokasian Menurut Desa Sumber Salak dengan Peraturan Permendagri

Menurut Desa Sumber Salak

Pengalokasian Menurut Desa Sumber Salak Dalam melakukan Pengalokasian di Desa Sumber Salak perlu fungsi pengawasan Badan Permusyawaratan Desa (BPD) Sebagai pengawas agar dana tersebut tersalurkan untuk kepentingan pembangunan di Desa. Pengawasan yang dilakukan oleh Badan Permusyawaratan Desa (BPD) melihat rencana awal yang dilakukan oleh Desa Sumber Salak serta besarnya Dana yang di butuhkan untuk melakukan pembangunan yang memang di rencanakan oleh Desa Sumber Salak dari situ bisa dijadikan patokan oleh BPD. Karena Pemerintah pusat mentransfer Dana Desa melihat dari luas wilayah, jumlah penduduk dan jumlah kemiskinan yang terjadi di Desa Sumber Salak, Setelah Dana yang diajukan oleh Desa SumberSalak turun Desa akan melakukan: a. Melakukan Pembangunan yang sudah tertera Di RKPBDes, b. Dalam melakukan pembangunan Desa akan di bantu oleh pendamping kegiatan (PK), c. Dalam setiap Pembangunan yang di lakukan Desa Sumber Salak harus dipertanggungjawabkan, d. Disetiap Pembangunan harus disusun SPJ, minimal pembangunan harus 
rampung 50\%, e. Dalam melakukan pembangunanya Desa Sumber Salak menggunakan SDM yang ada di desa Sumber Salak agar SDM yang ada di Desa bisa lebih berkembang.

Dalam melakukan pengalokasian desa Sumber Salak harus melihat dari Keadaan georafis dari luas wilayah, jumlah penduduk, dan angka kemiskinan karena dalam penyaluranya pemerintah melihat dari keadaan yang sebenarnya ada di DesaSumber Salak, agar dalam melakukan pengalokasian Desa Sumber Salak tidak mengalami kekurangan Dana.

\section{Menurut Peraturan Permendagri}

Pegalokasian menurut Permendagri bahwa pengalokasian Dana Desa dari APBN (Anggaran Pendapatan Belanja Negara) ke APBD (Anggaran Pendapatan Belanja Daerah) Kabupaten/Kota, Direktorat jendral perimbangan melakukan perhitungan Dana Desa setiap Kabupaten/Kota berdasarkan jumlah desa dan variable jumlah penduduk (30\%), luas wilayah (20\%), dan angka kemiskinan (50\%) yang dikalikan dengan indeks kemahalan kontruksi.

Penyaluran dana desa Sumber salak dilakukan secara bertahap pada tahun anggaran berjalan dengan ketentuan pada tahap pertama, pada bulan april sebesar $40 \%$, Tahap II, pada bulan agustus sebesar $40 \%$, dan pada tahap ke III, pada bulan oktober sebesar $20 \%$, penyaluran dana desa dari Rekening Kas Umum Negara (RKUN) ke Rekening Kas Umum Daerah (RKUD) kemudian ke Rekening kas Desa (RKDes), Rencana Kerja Pemerintah Desa (RKPMDes). Pengelolaan Dana Desa yang bersifat transparan, dimana nantinya pengelolaan Dana Desa Sumber Salak dilakukan secara terbuka segala bentuk kegiatan yang berhubungan dengan pengelolaan dana desa dan dapat diawasi langsung oleh pihak lain yang berwenang dan tidak ada yang ditutup-tutupi atau dirahasiakan karena Dana Desa sangat rentang disalah gunakan

Membandingan Mekanisme Pelaporan Menurut Desa Sumber Salak dengan Peraturan Permendagri Menurut Desa Sumber Salak. Pelaporan Dana Desa menurut Desa Sumber Salak adalah babakan terahir dari siklus pengelolaan Keuagan Desa, pengertian dan makna laporan, tahap, prosedur dan tatacara penyampaian yang dilakukan oleh Desa Sumber Salak dalam 1 Periode dan dipertanggungjawabkan oleh desa Sumber Salak itu sendiri dalam membuat laporan SPJ desa harus menyelesaikan pembangunan minimal 50\% cara Desa Sumber Salak membuat laporan Dana Desa dengan cara : a) Mengevaluasi kegiatan pembangunan yang ada di Desa Sumber Salak apakah dana yang diterima kurang atau lebih, b) Melihat apakah SPJ dalam setiap pembangunan sudah selesai dibuat, c) Melakukan Rapat Musrembangdes untuk merapat kegiatan yang sudah berlangsung selama 1 tahun penganggaran, d) BPD harus menyetui dulu laporan yang dibuat oleh Desa Sumber Salak, e) Setelah itu baru Desa Sumber Salak menyusun laporan Dana Desa.

Pelaporan Dana Desa menurut peraturan Permendagri Pemerintah Desa harus menyampaikan laporan realisasi pelaksanaan APBDes kepada Bupati, menyampaikan laporan penyelenggaraan pemerintah desa Desa (LPPD) setiap akhir tahun anggaran kepada Bupati/Walikota, Menyampaikan laporan keterangan penyelenggaraan pemerintah desa secara tertulis kepada BPD setiap akhir tahun anggaran.

Desa Sumber Salak sudah membuat laporan pertanggungjawaban dalam waktu satu anggaran Dana Desa. Tim pelaksana Desa Sebagai pemegang amanah melakukan pelaporan secara berkala kepada tim pendamping Kecamatan akan merekap laporan dari desa lalu dikirm ke Bupati. Desa Sumber Salak sudah mengikuti prosedur yang ada di peraturan Permendagri agar tidk terjadi kesalahan dalam membuat pelaporan yang ada di Desa Sumber Salak.

\section{Simpulan dan saran}

Berdasarkan hasil analisis dan pembahasan yang peneliti jelaskan maka dapat disimpulkan bahwa Evaluasi Penganggaran, Pengalokasian dan Pelaporan Dana Desa pengelolaan keuangan desa dalam proses pembangunan desa Sumber Salak Kecamatan Ledokombo Kabupaten Jember Tahun 2015 adalah sebagai berikut:

Perencanaan dalam pengelolaan Dana Desa di Desa Sumber Salak telah dilakukan dengan baik dan sesuai peraturan yang berlaku. Berdasarkan dalam perencanaan Dana Desa (Musrembangdes) ditingkat Desa, dan Musyawarah Dusun (Musdes) di tingkat Dusun yang melibatkan Badan Permusyawaratan Desa (BPD), Lembaga Pemberdayaan Masyarakat Desa (LPMD), Tim Pengelolaan Kegiatan (TPK) dan tokoh masyarakat. Tujuan dilakukan kegiatan Musrembangdes dan musdus ini adalah untuk menampung aspirasi dari semua pihak, baik pemerintah desa, dan dari masyarakat hingga diharapkan pembangunan Desa dilaksanakan sesuai dengan yang direncanakan di dalam Rencana Anggaran Biaya (RAB), tetapi di dalam Rencana Anggaran Biaya (RAB) memiliki angka yang tdak signifikan dengan Dana yang sudah terealisasi penggunaan Dana desa dan yang ada di APBDes. Berdasarkan nilai yang ada didalam Rencana 
Anggaran Biaya senila Rp. 11.951.269 dengan yang terealisasi di dalam penggunaan Dana Desa dan surat Permintaan Pembayaran (SPP) senilai Rp. 11.935 .793 ada perbedaan hasil ahir yang ada ddalam Rencana Anggaran Biaya (RAB) senilai 199.205.889 padahal yang ada di Anggaran Belanja Desa senilai 199.190.413 jadi hasil ahir tidak signifikan.

\section{Daftar Rujukan}

Abdul Wahab, Soliehin, 2000. Analisis Kebijakan dari Formulasi ke Implementasi Kebijakan Negara. Bumi aksara: Jakarta Agus Salim. 2002. Perubahan Sosial: Sketsa Teori dan Refrensi Metodologi Kasus di Indonesia. Yogyakarta: PT Tiara wacana.

Aldera, Antika 2014. Pengawasan Badan Permusnyawaratan Desa Terhadap Program Alokasi Dana Desa (Suatu studi Di Desa Pak Laheng Kecamatan Toho Kabupaten Pontianak).

Aswardi \& Sukanto. (2014). Efektivitas Alokasi Dana Desa (ADD) dan Kemiskinan di Provinsi Sumatera Selatan. Jurnal Ekonomi Pembangunan, Volume 12, Nomor 1, Halaman 29-41.

Darmada, D. K., Atmadja, A. T., \& Sinarwati, N. K. (2016). Kearifan Lokal Pade Gelahang dalam Mewujudkan Integrasi Akuntabilitas Pengelolaan Keuangan Organisasi Subak. Jurnal Akuntansi Multiparadigma, Volume 7, Nomor 1.

Grabowski, R. (2011). Indonesian Economic Development: Political Economy of an Effective State. Journal of the Asia Pacific Economy, Volume 16, Nomor 2, Halaman 241-253.

Liliana,Inten Meutia. 2017. Pengelolaan Keuangan Dana Desa. Jurnal Akuntansi Multiparadigma, Volume 8, Nomor 2.

Musmini, L. S., \& Sirajudin. (2016). Makna Akuntansi Sosial dan Sustainablitas Sekaa Suka Duka. Jurnal Akuntansi Multiparadigma, Volume 7, Nomor 2, Halaman156-170.

Niswatin \& Mahdalena. (2016). Nilai Kearifan Lokal "subak" Sebagai Modal Sosial Transmigran Etnis Bali. Jurnal Akuntansi Multiparadigma, Volume 7, Nomor 2, Halaman171- 188.

Rizaldy, N. (2012). Menemukan Lokalitas Biological Assets: Pelibatan Etnografis Petani Apel. Jurnal Akuntansi Multiparadigma, Volume 3, Nomor 3, Halaman 404-423.

Sari,Risya Novita dkk. 2015. Pengelolaan Alokasi Dana Desa Dalam Perspektif Pemberdayaan Masyarakat (Studi pada Kantor Pemerintahan Desa Ngasem, Kecamatan Ngasem, Kabupaten Kediri). Jurnal Administrasi Publik (JAP), Vol. 3, No. 11.

Saputra, I. W. (2016). Efektivitas Pengelolaan Alokasi Dana Desa pada Desa Lembean Kecamatan Kintamani, Kabupaten Bangli Tahun 2009-2014. Jurnal Jurusan Pendidikan Ekonomi (JJPE), Volume 6, Nomor 2, Halaman 1-10.

Setiawan, W., \& Barrett, P. S. (2016). The Built Environment Element of Economic Development in Post Conflict Response in Indonesia. Procedia Social and Behavioral Sciences, Volume 1, Nomor 2, Halaman 478-487.

Thomas. (2013). Pengelolaan Alokasi Dana Desa dalam Upaya Meningkatkan Pembangunan di Desa Sebawang, Kecamatan Sesayap, Kabupaten Tana Tidung. Jurnal Pemerintahan Integratif, Volume 1, Nomor 1, Halaman 51-64. 